\title{
Visual outcome after ND: YA Glaser posterior capsulotomy in pseudophakic patient
}

\author{
Verma A. ${ }^{1}$, Singh A. ${ }^{2}$, Patel S. ${ }^{3}$, Rana R. ${ }^{4}$, Jain P. ${ }^{5}$ \\ ${ }^{1}$ Dr. Abha Verma, Associate Professor, ${ }^{2}$ Dr. Ankit Singh, Senior Resident; above two authors are attached with \\ Department of Ophthalmology, Aurobindo Medical College and Postgraduate Institute, Indore (M.P.), ${ }^{3}$ Dr. Siddharth \\ Patel, Senior Resident, All India Institute of Medical Sciences, Rishikesh, ${ }^{4}$ Dr. Rimpi Rana, Senior Resident, All India \\ Institute of Medical Sciences, Rishikesh, ${ }^{5}$ Dr. Pragati Jain, Junior Resident, Department of Ophthalmology, Shri \\ Aurobindo Medical College and Postgraduate Institute, Indore, M.P, India.
}

Corresponding Author: Dr. Abha Verma, Associate Professor, Department of Ophthalmology, Aurobindo Medical College and Postgraduate Institute, Indore, M.P., India, Email: drabhaverma17@gmail.com

\begin{abstract}
Background: Posterior capsular opacification (PCO) also called as "after cataract" is a common complication following extra capsular cataract surgery with or without posterior chamber intraocular lens implantation.An opaque membrane develops as retained cells proliferate and migrate on the posterior capsular surface. Material and Methods: The study included a total of 100 eyes of 100 patients who were diagnosed to have posterior capsular opacification and were fulfilling all the inclusion and none of the exclusion criteria. After that they were taken for a detailed clinical examination. All patients underwent Nd: YAG laser capsulotomy and were followed up at 1 week, 1 month and at 3 months. At every follow-up detailed examination was done. BCVA and any complications were noted. Results: Of the 100 patients, $45(45 \%)$ were male and $55(55 \%)$ were female. Majority of the patients were in the age group 61-70 years. The average time interval between cataract surgery and Nd-YAG laser capsulotomy was between 2-4 years. In the type of PCO seen, $84(84.0 \%)$ patients were having Elsching pearls type of PCO, $8(8.0 \%)$ patients were having fibrous type of PCO and $8(8.0 \%)$ patients were having Sommering ring type of PCO. The pre laser visual acuityin more than $62 \%$ of eyes was $6 / 60$ to FC while $38 \%$ had visual acuity of $6 / 36$ to $6 / 18$. Visual acuity of $6 / 18$ or better was achieved in $27 \%$ of eyes while $73 \%$ recovered to $6 / 12$ to $6 / 6$. None of these eyes showed further deterioration in visual acuity. The highest energy requirement was in the Fibrous PCO s0.89 $\pm 0.15 \mathrm{~J}$, followed by Sommering Ring PCO $0.70 \pm 0.17 \mathrm{~J}$ and least energy was in Elsching pearls $0.47 \pm 0.24 \mathrm{~J}$. The comparison of mean energy between the type of PCO was found to be statistically significant $(\mathrm{P}<0.05)$, showing that the mean energy was varying between the types of PCO. Conclusion: Neodymium-YAG capsulotomy for PCO is rewarding procedure inadults and has good visual outcome.
\end{abstract}

Keywords: Posterior capsular opacification, Nd-YAG, Visual outcome

\section{Introduction}

Cataract is the main cause of avoidable blindness [1]. Despite some recent advances in the field of cataract potential drug treatments, surgery is still acknowledged to be the most effective treatment option [2]. Despite the meticulous surgery and removal of the cataractous lens, the lens epithelial cell stillposes a threat to the long-term outcome of the surgery. Postoperative opacification of initially clear posterior capsules occurs frequently in patients after the surgery. Time for opacification is highly variable varying from months to years in adults. The most convenient way of the

Manuscript received: $20^{\text {th }}$ July 2018

Reviewed: $30^{\text {th }}$ July 2018

Author Corrected: $4^{\text {th }}$ August 2018

Accepted for Publication: $9^{\text {th }}$ August 2018 removal of the posterior capsule opacification is toclearing the visual axis by creating a central opening in the opacified posterior capsule using Nd - YAG laser [3]. It is a solid-state laser with a wave length of 1064 $\mathrm{nm}$ that can disrupt ocular tissues by achieving optical breakdown with a short, high-power pulseresulting in ionization, or plasma formation that causes acoustic and shock waves that disrupt tissue.

Contraindications to laser capsulotomy can be divided into absolute and relative. Corneal scars, irregularities, or edema that interfere with target visualization or make optical breakdown unpredictable and inadequate stability of the eye are absolute contraindications while 
glass intraocular lens, known or suspected cystoid macular edema, active intraocular inflammation, high risk for retinal detachment are relative contraindications.

\section{Purpose}

Primary: To study the visual outcome post capsulotomy after the cataract surgery

Secondary: To assess the energy required in ND: YAG for different types of the PCO

\section{Material and Methods}

Consent from ethical committee for the study was taken. The procedures followed were in accordance with the ethical standards committee on human experimentation (institutional or regional) and with the Helsinki Declaration of 1975, as revised in 2000. The present study was a cross sectional study and included 100 patients attending outpatient Department of Ophthalmology from January 2017 to January 2018 and willing to provide their voluntary written informed consent. Consent from each patient was taken before the procedure.

Pre laser work up: Each patient was thoroughly evaluated with the help of slit lamp. Best corrected visual acuity (BCVA) was noted along with IOP. Both the pupils were dilated using a short acting mydriatic drug $(0.8 \%$ tropicamide and $5 \%$ phenyephrine $)$ and then the patient was made to sit for 30 minutes. After 30 minutes the dilatation of the pupil was assessed along with complete slit lamp examination. On slit lamp the type of PCO was assessedand 5-step photography was done, followed by fundus examination with VOLK 90D orindirect 20D lens.

Procedure: Topical anaestheticwas instilled in the eye tobe lasered. The patient was made to sit on ZEISS ND: YAG laser machine. The Abraham yag capsulotomy lens was fixed on the eye with the help of viscoelastic. The energy of the laser was fixed and then shots were taken and modified according to type of PCO.

Post laser work up and follow up: After the procedure, the patient was made to sit for 10 to 15 minutes. Post Yagprocedure topical beta blocker was instilled into the lasered eye and then the patient was asked to come for follow-up after 1 week.

The patient was sent home with a topical antibiotic drop along with a mild steroid (dexamethasone) to be instilled 4 times a day for 1 week.

Along with this a beta blocker was added to be instilled twice a day for 1 week. At 1 week follow-up the IOP and BCVA of the patient was recorded.

All the data was recorded in a customized proforma designed for the study purpose.

\section{Results}

In our study 100 patients were studied which included 55 (55.0\%) females and 45 (45.0\%) males, showing a female preponderance. There were $7(7.0 \%)$ patients in the age group 30-40 years, $14(14.0 \%)$ patients were in the age group $41-$ 50 years, $31(31.0 \%)$ patients were in the age group 51-60 years, $36(36.0 \%)$ patients were in the age group 61-70, 10 $(10.0 \%)$ patients were in the age group 71-80 years and $2(2.0 \%)$ patients were in the age group >80 years.Majority of the patients were in the age group 61-70 years(36\%).

$84(84.0 \%)$ patients were having Elsching pearls type of PCO (Figure 1), 8 (8.0\%) patients were having fibrous type of PCO (Figure 2) and $8(8.0 \%)$ patients were having Sommering ring type of PCO (Figure 3). Majority of the patients were having Elsching pearls type of PCO [Figure 4].

The mean age in Elsching pearls was $60.36 \pm 11.46$ years, in Fibrous it was $60.50 \pm 10.66$ years and in the Sommering Ring it was $56.75 \pm 14.46$ years. The comparison was found to be statistically not significant $(\mathrm{P}>0.05)$. There was comparable distribution of males and females in relation to type of PCO $(\mathrm{P}>0.05)$.

The time interval between cataract surgery and Nd-YAG laser capsulotomy was noted. 25 (25.0\%) patients had duration from surgery from 1-2 years, $62(62.0 \%)$ patients had duration from surgery from 2-4 years and $13(13.0 \%)$ patients had duration from surgery of more than 4 years. Most of the patients had duration from surgery between 2-4 years (62\%).

In $38(38.0 \%)$ patients the pre-YAG vision was $6 / 36$ to $6 / 18$ and in $62(62.0 \%)$ patients the pre-YAG vision was FC to 6/60. Post YAG, in 73 (73.0\%) patients the Post-YAG vision was 6/12 to 6/6 and in 27 (27.0\%) patients the Post-YAG Vision was 6/36 to 6/18. Majority of the patients were having Post-YAG Vision of 6/12 to 6/6. [Figure 5]. 


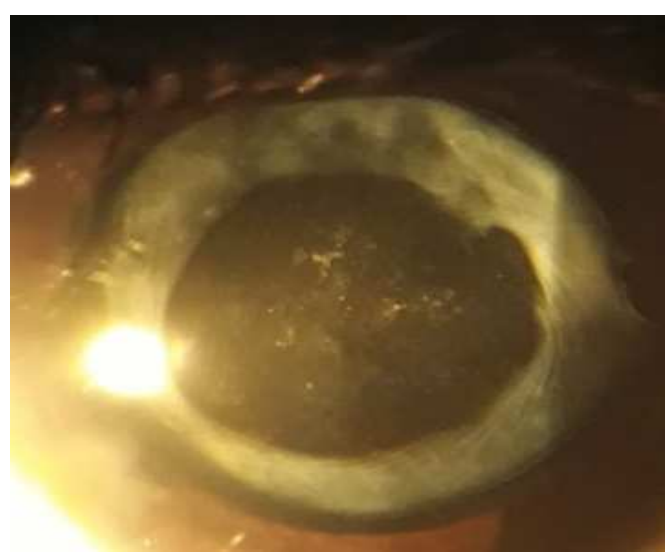

Figure-1: Elsching's pearls

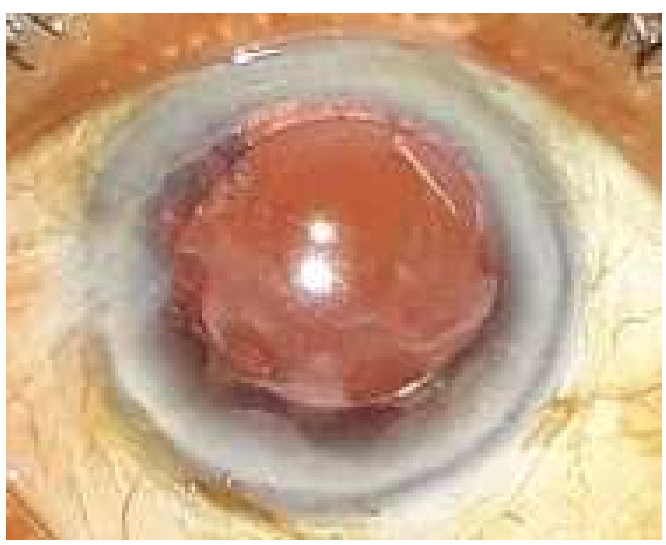

Figure-2: Fibrous type

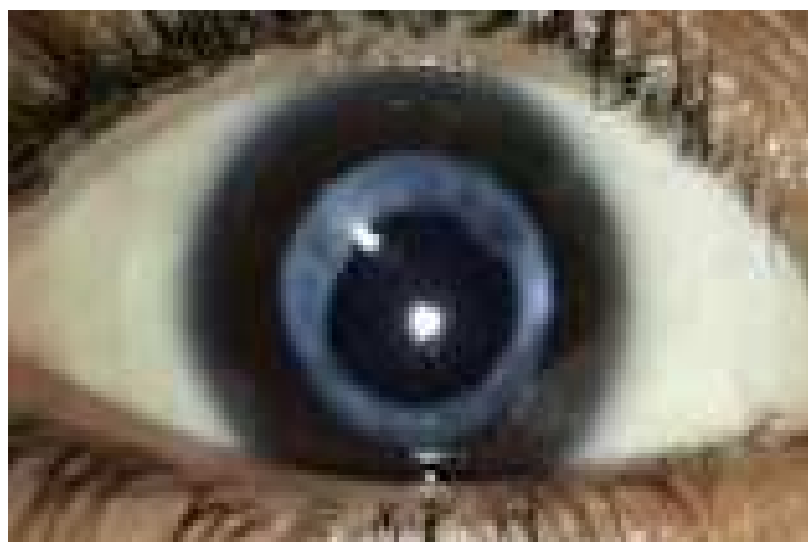

Figure-3: Sommering ring

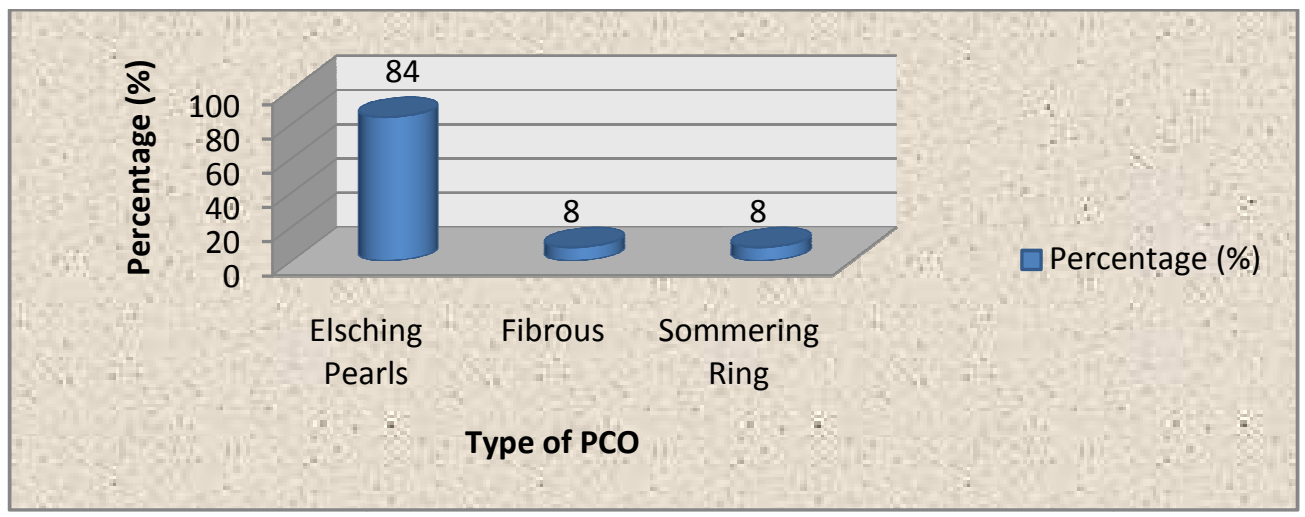

Figure-4: Distribution according to the type of PCO

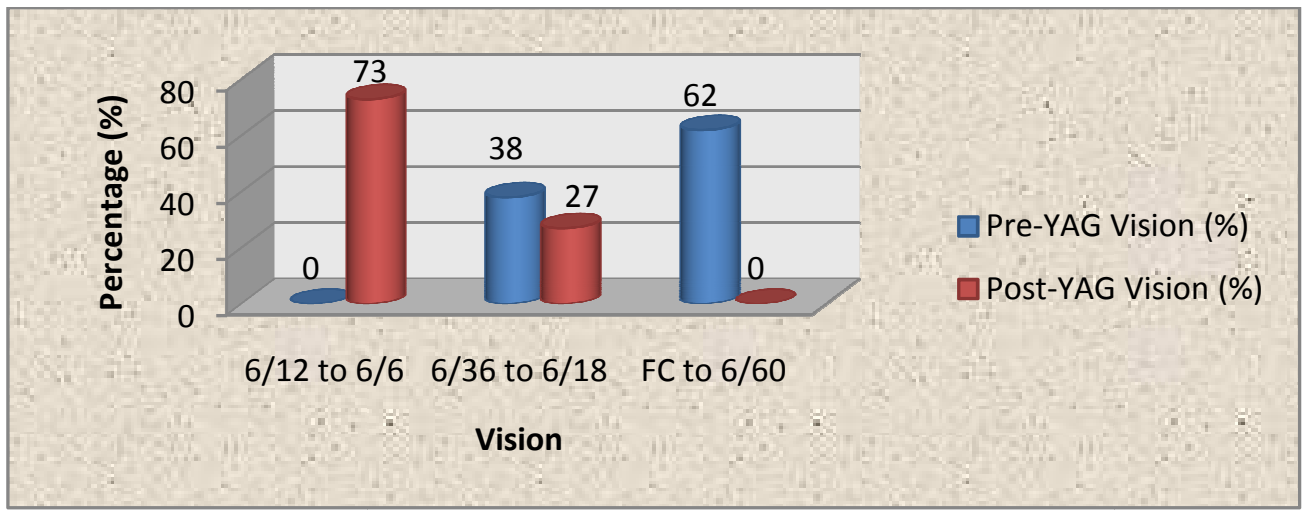

Figure-5: Comparison of pre and post-YAG vision 
Table-1: Comparison of mean IOP in before and after YAG treatment in relation to PCO

\begin{tabular}{|c|c|c|c|c|c|}
\hline Type of PCO & IOP & No. & $\begin{array}{c}\text { IOP } \\
{[\text { Mean } \pm \text { SD }]}\end{array}$ & 't' value & P value \\
\hline \multirow{2}{*}{ Elsching Pearls } & Pre YAG IOP & 84 & $16.79 \pm 2.03$ & \multirow{2}{*}{$2.053, \mathrm{df}=83$} & \multirow{2}{*}{$0.043 *$} \\
\hline & Post YAG IOP & 84 & $16.18 \pm 2.43$ & & \\
\hline \multirow{2}{*}{ Fibrous } & Pre YAG IOP & 8 & $16.25 \pm 3.28$ & \multirow{2}{*}{$2.049, \mathrm{df}=83$} & \multirow{2}{*}{$0.080, \mathrm{NS}$} \\
\hline & Post YAG IOP & 8 & $14.00 \pm 1.07$ & & \\
\hline \multirow{2}{*}{ Sommering Ring } & Pre YAG IOP & 8 & $15.00 \pm 2.39$ & \multirow{2}{*}{-} & \multirow{2}{*}{-} \\
\hline & Post YAG IOP & 8 & $15.00 \pm 2.39$ & & \\
\hline \multirow{2}{*}{ Overall } & Pre YAG IOP & 100 & $16.61 \pm 2.21$ & \multirow{2}{*}{$2.587, \mathrm{df}=99$} & \multirow{2}{*}{$0.011^{*}$} \\
\hline & Post YAG IOP & 100 & $15.91 \pm 2.42$ & & \\
\hline
\end{tabular}

The comparison of mean IOP before and after YAG treatment in relation to type of PCO was done using paired ' $\mathrm{t}$ ' test. The mean Pre YAG IOP in Elsching Pearls was $16.79 \pm 2.03 \mathrm{~mm} \mathrm{Hg}$, while post YAG IOP was $16.18 \pm 2.43 \mathrm{~mm} \mathrm{Hg}$. The difference was found to be statistically significant $(\mathrm{P}<0.05)$, showing that there is a significant decrease in the Post YAG IOP in comparison to the Pre YAG IOP in the Elsching Pearls. The mean Pre YAG IOP in Fibrous was $16.25 \pm$ $3.28 \mathrm{~mm} \mathrm{Hg}$, while post YAG IOP was $14.00 \pm 1.07 \mathrm{~mm} \mathrm{Hg}$. The difference was found to be statistically not significant ( $\mathrm{P}>0.05)$, showing a comparable Post YAG IOP in comparison to the Pre YAG IOP.The mean Pre YAG IOP in Sommering Ring was $15.00 \pm 2.39 \mathrm{~mm} \mathrm{Hg}$, while post YAG IOP was $15.00 \pm 2.39 \mathrm{~mm} \mathrm{Hg}$. The difference could not be calculated as the difference of the standard deviation of pre and post YAG IOP was found to be zero. The mean overall Pre YAG IOP was $16.61 \pm 2.21 \mathrm{~mm} \mathrm{Hg}$, while post YAG IOP was $15.91 \pm 2.42 \mathrm{~mm} \mathrm{Hg}$. The difference was found to be statistically significant $(\mathrm{P}<0.05)$, showing that there is a significant decrease in the overall Post YAG IOP in comparison to the overall Pre YAG IOP [Table 1].

Table-2: Comparison of mean energy in relation to type of PCO

\begin{tabular}{|c|c|c|c|c|c|c|c|}
\hline \multirow[t]{2}{*}{ Type of PCO } & \multirow[t]{2}{*}{ Number } & \multirow[t]{2}{*}{ Mean \pm SD } & \multirow[t]{2}{*}{ F value } & \multirow[t]{2}{*}{$P$ value } & \multicolumn{3}{|c|}{ Post-hoc Tukey } \\
\hline & & & & & $\begin{array}{l}\text { Elsching } \\
\text { Pearls - } \\
\text { Fibrous }\end{array}$ & $\begin{array}{c}\text { Elsching Pearls } \\
\text { - Sommering } \\
\text { Ring }\end{array}$ & $\begin{array}{c}\text { Fibrous - } \\
\text { Sommering } \\
\text { Ring }\end{array}$ \\
\hline Elsching Pearls & 84 & $0.47 \pm 0.24$ & \multirow{3}{*}{14.732} & \multirow{3}{*}{$0.000^{*}$} & \multirow{4}{*}{$0.000 *$} & \multirow{4}{*}{$0.021 *$} & \multirow{4}{*}{$0.242, \mathrm{NS}$} \\
\hline Fibrous & 8 & $0.89 \pm 0.15$ & & & & & \\
\hline $\begin{array}{l}\text { Sommering } \\
\text { Ring }\end{array}$ & 8 & $0.70 \pm 0.17$ & & & & & \\
\hline Total & 100 & & & & & & \\
\hline
\end{tabular}

The mean energy in Elsching pearls was $0.47 \pm 0.24 \mathrm{~J}$, in Fibrous it was $0.89 \pm 0.15 \mathrm{~J}$ and in the Sommering Ring it was $0.70 \pm 0.17 \mathrm{~J}$. The highest energy was in the Fibrous PCO. The comparison of mean energy between the type of PCO was found to be statistically significant $(\mathrm{P}<0.05)$, showing that the mean energy was varying between the types of PCO. There was significantly lower energy in Elsching Pearls in comparison to the Fibrous and Sommering Ring PCOs (P<0.05), while no statistically significant difference seen between Fibrous and Sommering Ring $(\mathrm{P}>0.05)$. [Table 2]

Table-3: Comparison of mean number of YAG shots in relation to type of PCO.

\begin{tabular}{|c|c|c|c|c|c|c|c|}
\hline \multirow[t]{2}{*}{ Type of PCO } & \multirow[t]{2}{*}{ Number } & \multirow[t]{2}{*}{ Mean \pm SD } & \multirow[t]{2}{*}{ F value } & \multirow[t]{2}{*}{ P value } & \multicolumn{3}{|c|}{ Post-hoc Tukey } \\
\hline & & & & & $\begin{array}{l}\text { Elsching } \\
\text { Pearls - } \\
\text { Fibrous }\end{array}$ & $\begin{array}{c}\text { Elsching Pearls } \\
\text { - Sommering } \\
\text { Ring }\end{array}$ & $\begin{array}{l}\text { Fibrous - } \\
\text { Sommering } \\
\text { Ring }\end{array}$ \\
\hline Elsching Pearls & 84 & $107.56 \pm 17.18$ & \multirow{3}{*}{2.923} & \multirow{3}{*}{$\begin{array}{c}0.059 \\
\mathrm{NS}\end{array}$} & \multirow{4}{*}{$\begin{array}{c}0.360 \\
\text { NS }\end{array}$} & \multirow{4}{*}{$0.094, \mathrm{NS}$} & \multirow{4}{*}{$0.851, \mathrm{NS}$} \\
\hline Fibrous & 8 & $99.38 \pm 9.94$ & & & & & \\
\hline $\begin{array}{l}\text { Sommering } \\
\text { Ring }\end{array}$ & 8 & $95.00 \pm 3.46$ & & & & & \\
\hline Total & 100 & & & & & & \\
\hline
\end{tabular}


The mean number of YAG shots in Elsching pearls was $107.56 \pm 17.18$, in Fibrous it was $99.38 \pm 9.94$ and in the Sommering Ring it was $95.00 \pm 3.46$. The comparison of mean number of YAG shots between the type of PCO was found to be statistically not significant $(\mathrm{P}>0.05)$, showing that the mean number of YAG shots was comparable in relation type of PCO. [Table 3]

\section{Discussion}

Age and sex- A total of 100 patients were studied who presented with PCO post cataract surgery between the ages of 30 to those over 80 years, with most the patients $36 \%$ falling between the ages of 61-70 years. The sex distribution was a $55 \%$ female to $45 \%$ male ratio with female preponderance.

Opacification post-surgery- The Neodymium- YAG laser has become popular non-invasive technique of creating a posterior capsulotomy to create an opening in the posterior lens. Its safety and efficacy can be argued but it has established its place as a standard treatment for PCO replacing surgical capsulotomy. The time period between cataract extraction and performing Neodymium-YAG laser capsulotomy at average was 24 years in our study while it was reported as 2.49 years by Hasan et al [4], and 24 months in another study by Kundi NK et al [5]. Emery, Wilhelmus, and Rosenberg [6] found opacification in $28 \%$ of their patients with 2-3 years of follow-up. Late opacification of the posterior capsule after 3-5 years has been reported to be approximately $50 \%$.

Visual Acuity post treatment- According to our findings the Post- YAG Vision in $73.0 \%$ patients was $6 / 12$ to $6 / 6$ and in $27.0 \%$ patients the Post-YAG Vision was $6 / 36$ to $6 / 18$. Majority of the patients were having Post-YAG Vision of $6 / 12$ to $6 / 6$. In a study by Bilal Bashir et al[4] the post treatment visual acuity was $6 / 6$ in $12(40 \%), 6 / 9$ in $9(30 \%)$ patients, $6 / 12$ in $6(20 \%)$ patients and 6/18 in $2(6.66 \%)$ and 6/24 in 1(3.33\%) patients. A study conducted by Younas Khan et al[8] showed post-YAG Visual acuity of $6 / 18$ or better was achieved in $60.2 \%$ of eyes while $12.0 \%$ recovered to $6 / 9$ and $3.4 \%$ achieved $6 / 6$.

Types of PCO- In our study, according to type of PCO studied, $84.0 \%$ patients had Elsching pearls type of PCO, $8.0 \%$ patients were having fibrous type of PCO and $8.0 \%$ patients hadSommering ring type of PCO. Hence, majority of the patients were having Elsching pearls type of PCO. However a study by Younas Khan et al [8] showed Capsular fibrosis (62\%) was the predominant type of $\mathrm{PCO}$. The relative incidence of different types of PCO showed that the capsular fibrosis was the predominant type of PCO as compared to Hasan, et al [4] who reported Elschnig's pearls in pseudophakic and secondary fibrosis in aphakic eyes.
Complications- Elevated IOP is recognized as the most common, although usually transient, complication following Nd: YAG laser capsulotomy. This is similar to a study done by Gopinath et al [9] where they found increased IOP in $30 \%$ patients, but the rise was mostly in the range of 21-27 mm Hg. However in our study we found the mean overall Pre YAG IOP was $16.61 \pm 2.21$ $\mathrm{mm} \mathrm{Hg}$, while post YAG IOP was $15.91 \pm 2.42 \mathrm{~mm} \mathrm{Hg}$. There is a significant decrease in the overall Post YAG IOP in comparison to the overall Pre YAG IOP.

YAG shots, energy used- Only few cases in required high energy levels, probably this may correlate with the learning curve. Once the surgeon get experienced the energy level required can come down, the other reason may be the fixation of eyes required during the process, if the patient moves the eye, the energy level will be more, as the shots are wasted, hence fixating lens should be used to decrease the level of energy and shots [10]. The mean energy in Elsching pearls was $0.47 \pm$ $0.24 \mathrm{~J}$, in Fibrous it was $0.89 \pm 0.15 \mathrm{~J}$ and in the Sommering Ring it was $0.70 \pm 0.17 \mathrm{~J}$. The highest energy was in the Fibrous PCO. In the comparison of number of YAG shots in relation to type of PCO. The mean number of YAG shots in Elsching pearls was $107.56 \pm 17.18$, in Fibrous it was $99.38 \pm 9.94$ and in the Sommering Ring it was $95.00 \pm 3.46$.

\section{Conclusion}

Nd: YAG laser capsulotomy is asafe and effective method to treat PCO. It is non-invasive and avoids all the complications associated with surgical capsulotomy such as endophthalmitis and wound related problems and local anaesthesia such as perforation and haemorrage etc. Majority of the patients were in the age group 61-70 years.

Elsching's pearls were present in maximum patients. Majority of patients had significant improvement in visual acuity with $73 \%$ having visual improvement between $6 / 6$ to $6 / 12$. There is a significant decrease in the overall Post YAG IOP in comparison to the overall Pre YAG IOP. Corneal oedema and iritis were seen as post laser complications. Funding: Nil, Conflict of interest: Nil
Permission from IRB: Yes 


\section{References}

1. Swenor BK, Simonsick EM, Ferrucci L, Newman $\mathrm{AB}$, Rubin S, Wilson V. Visual impairment and incident mobility limitations: the health, aging and body composition study. J Am Geriatr Soc. 2015; 63(1):4654. doi:10.1111/jgs.13183

2. Keeffe J, Taylor HR, Fotis K, Pesudovs K, Flaxman SR, Jonas JB, Leasher J, Naidoo K, Price H, White RA, Wong TY, Resnikoff S, Bourne RR, Vision Loss Expert Group of the Global Burden of Disease Study Prevalence and causes of vision loss in Southeast Asia and Oceania: 1990-2010. Br J Ophthalmol. 2014; 95 (8): 586-591.doi: 10.1136/bjophthalmol-2013-304050

3. Apple DJ, Peng Q, Visessook N, et al. Eradication of posterior capsule opacification: documentation of a marked decrease in Nd: YA Glaser posterior capsulotomy rates noted in an analysis of 5416 pseudophakic human eyes obtained postmortem. Ophthalmology. 2001 Mar; 108 (3):505-18.

4. Hasan KS, Adhi MI, Aziz M, et al. Nd:YAG laser posterior capsulotomy. Pak Ophthalmol. 1996; 12: 3-7.
5. Kundi NK, Younas M. Nd-YAG Laser posterior capsulotomy. J Med Sciences. 1998; 8: 90-4.

6. Emery J. Capsular opacification after cataract surgery. CurrOpinOphthalmol. 1999 Feb;10(1):73-80.

7. Bilal Bashir et al. Visual outcome after Nd: Yag Laser Anterior Capsulotomy in Patients with Anterior Capsular Contraction Syndrome. Ophthalmology Update Vol. 12. No. 4, October-December 2014

8. Mohammad Younas Khan et al. Visual Outcome after Nd-YAG Capsulotomy in Posterior Capsule Opacification. Pak J Ophthalmol 2006, Vol. 22 No.2

9. Gopinath GS, Satish K, Srivastava N, Patil S, Afshan R. Visual Outcome and Complications of YAG Laser Therapy for Posterior Capsular Opacification Following Cataract Surgery. Int J Sci Stud 2015;3(3):65-68.

10. Pankaj Soni et al. Nd-YAG laser posterior capsulotomy and visual outcome. Indian Journal of Clinical and Experimental Ophthalmology, JulySeptember, 2016; 2(3): 271-27

\section{How to cite this article?}

Verma A, Singh A, Patel S, Rana R, Jain P. Visual outcome after ND: YA Glaser posterior capsulotomy in pseudophakic patient. Trop J Ophthalmol Otolaryngol.2018;3(3):33-38.doi:10.17511/jooo.2018.i03.05 